Article

\title{
An Auditing Framework for Knowledge-Enabled Supply Chain Management: Implications for Sustainability
}

\author{
Abdelkader Daghfous ${ }^{1}$ and Taisier Zoubi ${ }^{2, *}$ \\ 1 Department of Marketing and Information Systems, School of Business Administration, \\ American University of Sharjah, P.O. Box 26666, Sharjah, UAE; adaghfous@aus.edu \\ 2 Department of Accounting, School of Business Administration, American University of Sharjah, \\ P.O. Box 26666, Sharjah, UAE \\ * Correspondence: tzoubi@aus.edu; Tel.: +971-6-515-2367
}

Academic Editor: Fabio Carlucci

Received: 26 March 2017; Accepted: 25 April 2017; Published: 10 May 2017

\begin{abstract}
Knowledge management (KM) plays a key role in the success of several enterprise systems, such as supply chain management (SCM). This paper discusses knowledge-enabled supply chain management (K-SCM) as it enhances the organizations' expertise in SCM. We propose a framework that integrates KM processes with SCM components. We developed an audit methodology that can be performed to assess the organization's readiness in K-SCM. The developed framework consists of KM dimensions and Supply Chain Operations Reference (SCOR) components. The proposed audit methodology is subsequently illustrated through a case of a manufacturing company based in the United Arab Emirates (UAE). The paper concludes with implications for managerial practice and future research, with a special focus on sustainable SCM.
\end{abstract}

Keywords: knowledge management; knowledge audit; supply chain management; sustainability

\section{Introduction}

Global companies have always faced serious challenges in managing their supply chains because of continually-increasing customers' expectations. In recent years, this challenge has intensified with the pressure of globalization and through the proliferation of new knowledge related to enterprise information systems, shorter product life cycles, increasingly complex supply chains, and constantly changing customer demands [1]. Driven by these forces, we are in the midst of an economic transition from an era of competitive advantage based on information to an era of knowledge creation and KM.

The concepts of SCM and KM have recently gained wide attention in business and academia. Both fields focus on allocating resources to support business activities in order to gain a competitive advantage. Although they currently represent two different research areas, we see a high synergy potential in an integrated approach [2]. Intangibles, such as supplier relationship, are becoming ever more important than tangibles, such as off-the-shelf systems and technologies [3]. This increasingly knowledge-driven nature of competition is motivating change in how business systems are being managed [4]. Furthermore, in order to excel in SCM systems, companies are moving from cost-focused supply chain improvements like third-party logistics to knowledge-focused supply chain improvements by focusing on improving their knowledge and expertise in SCM [5].

Consequently, integrating SCM with KM has created the concept of knowledge-enabled SCM (K-SCM), which allows companies to continuously upgrade the level of skills and knowledge by generating, documenting, sharing, and utilizing the latest knowledge and knowledge-based processes [6]. K-SCM also enables the focal firm to understand changes in the supplier market 
and be more effective in developing suppliers, which would produce successful supplier relationships that cannot be easily imitated by competition [7]. In addition, one of the critical first steps in engaging in KM initiatives is to conduct a knowledge audit. This paper builds on and extends prior studies by Daghfous et al. [8] and Daghfous and Khawaja [9] which identified and discussed the knowledge-enabled Customer Relationship Management (CRM) and K-SCM audit, respectively. Unlike K-SCM, the KCRM knowledge audit focuses on the downstream side of the focal firm's supply chain by integrating the KM, auditing, and CRM literatures.

In this paper, we focus on the upstream side of the focal firm's supply chain and show how knowledge auditing can help build a foundation for K-SCM by determining what knowledge is needed, what is available and missing, who needs this knowledge and how it would be applied. First, a literature review is provided about auditing, SCM, and KM. Then, the methodological approach and the proposed framework on K-SCM knowledge auditing are discussed in details. Subsequently, an illustrative case study is conducted by applying the framework to a UAE-based manufacturing company. We conclude the paper with implications for future research, especially in the area of sustainable SCM.

\section{Auditing and the Knowledge Audit}

Organizations are increasingly looking for ways to improve performance. One way to do that is by conducting an audit to identify gaps, evaluate processes, people, and systems, and assess whether they are achieving goals related to efficiency and effectiveness. The most general definition of an audit is "an evaluation of a person, organization, system, process, project or product" [10]. Due to practical constraints, an audit seeks to provide only reasonable assurance that the statements are free from material error.

The first step in KM initiatives is to identify where knowledge exists, created, and needed. Using a knowledge audit as a first step in developing a KM strategy could ensure that the organization is managing what is actually needed. According to Choy et al. [11], there are five components of a knowledge audit, namely (1) pre-audit preparation, (2) employee questionnaire surveys, (3) face-to-face interviews, (4) inventory of corporate knowledge assets, and (5) knowledge map development [11]. Later, Cheung et al. [12] argued that knowledge audits can provide an evidence-based assessment of where and how the organization needs to focus its KM effort. They proposed a systematic knowledge audit approach comprised of eight phases: (1) orientation and background study, (2) cultural assessment, (3) in-depth investigation, (4) building knowledge inventory and knowledge mapping, (5) knowledge network analysis and social network analysis, (6) recommendation of knowledge management strategy, (7) deployment of KM tools and building collaborative culture, and (8) continuous knowledge re-auditing. In contrast, Wang and Xiao [13] proposed a four stage knowledge audit framework based on process. These four stages are: (1) preparatory stage, (2) analysis stage, (3) implementation stage, and (4) summary stage. Most recently, Yip et al. [14] relied on a knowledge audit methodology composed of three components as they distinguished between structured and unstructured business processes. These three components are: (1) knowledge elicitation, (2) knowledge representation, and (3) role of the researcher.

\section{Supply Chain Management}

Through effective management of the supply chain, an organization adds value to customers and various other stakeholders in terms of providing quality and efficiency in products and services. SCM has originated in the manufacturing industry and has since been implemented in various industries, including services such as retail [15]. SCM research has examined a number of problems, challenges, and opportunities to improve and even optimize functions and systems ranging from procurement of raw materials, assembly of components, to delivery of finished products to distribution centers and end customers. 
New knowledge and IT have created the opportunity for companies to overcome problems in managing their supply chains. In response to these challenges, more companies are moving from cost-focused supply chain improvements to knowledge-enabled supply chain improvements by augmenting their expertise in SCM, often making it a sustainable source of competitive advantage. Although connectivity and new enterprise software solutions have acted as enablers of collaboration and information integration, most organizations still have to reassess their system of generating, documenting, distributing, and utilizing relevant knowledge about SCM.

As firms seek to demonstrate a more ethical approach to purchasing, among various SCM processes and activities, sustainable and green SCM has become a major research stream within SCM to keep pace with a growing global environmental awareness. This has translated into numerous international conferences, books, and dedicated special issues in leading journals. Srivastava [16] presented a comprehensive and integrated overview of the literature on green SCM, which he defined as "integrating environmental thinking into SCM, including product design, materials sourcing and selection, manufacturing processes, delivery of the final product to the consumers as well as end-of-life management of the product after its useful life. More recently, Carter and Easton [17] reviewed the sustainable SCM (SSCM) literature in the main logistics and SCM journals, across a 20-year time frame [17]. Other related studies focused on other areas of SSCM such as environmental logistics strategies and logistics social responsibility [18].

\subsection{The SCOR Model}

The SCOR model was approved in 1996 by Supply Chain Council (SCC) which is owned by the American Production and Inventory Control Society (APICS) for organizations' use in the SCM sector around the world. As Theeranuphattana and Tang [19] put it, "The SCOR model' framework can be used as a business process reference model, which provides a framework (toolkit) that includes supply chain business processes, metrics, best practices, and technology features". The SCOR model has also been a suitable supply chain model used in industrial settings around the world. Moreover, it provides clarity and permits supply chain members to more easily reach an agreement on how to define supply chain metrics. Indeed, the SCOR model allows supply chain partners to "speak a common language" since it "provides standardized definitions for processes, process elements, and metrics. In relation to sustainability and SSCM, the SCOR model was also extended into what is termed GreenSCOR by integrating environmental considerations through processes, metrics, and best practices into SCM processes [20].

\subsection{The SCOR Model Components}

The SCOR model separates supply chain operations into five main elements or categories, which are used in SCM decision making. These elements are: (1) plan, (2) source, (3) make, (4) deliver, and (5) return. In order to balance resources with requirements and meet customers' demand in an efficient and effective way, a firm should develop a strategy to manage all the necessary resources. In the planning stage of the SCOR model, the focal firm develops standards of measurement by which cost, efficiency, quality and value to customers can be assessed [21]. The focal firm selects, then, the suppliers that would deliver the goods and services needed to create products and services. The next step (i.e., sourcing) is to develop a set of pricing, delivery, and payment processes with vendors and establish standards that can be used to monitor and improve the relationships with suppliers. The firm establishes procedures to manage inventory and services which include receiving, verifying and transferring shipments to the factory.

In the manufacturing stage (make), the firm establishes a timetable of all the activities needed for production, testing, packaging and preparation for delivery of the products. Subsequently, the next step is referred to by many industry insiders as logistics. In this "deliver" stage, the firm synchronizes the orders received from potential customers, designs a warehouse network, chooses transportation carriers to deliver the products to the customers, and establishes an invoicing system to handle 
payments received from customers. The final stage in the SCOR model is "return", which is often referred to as reverse logistics. It is the process of managing products returned by customers, replacements, recycling, or simply disposing of excess products.

\section{Knowledge Management}

As the business environment becomes ever more complex and turbulent, organizations increasingly struggle to manage their distinctive knowledge to gain a sustainable competitive advantage [22]. In this paper, we define knowledge as a "fluid mix of framed experience, values, contextual information and expert insight that provide a framework for evaluating and incorporating new experiences and information" [23]. Hence, we argue that knowledge is the result of an incessant dialogue between explicit and tacit knowledge. While explicit knowledge is generally readily available in a form that can be shared and managed, tacit knowledge provides a management challenge as it generally resides within the heads of individuals [24,25]. Managers, seeking effective methods to convert tacit into explicit knowledge, and to develop a knowledge-oriented culture have turned to formal KM programs to generate, codify, distribute, and utilize this tacit knowledge for wider uses across the firm [2,26]. KM is perceived as a set of interrelated and interdependent functions or processes. These processes include knowledge creation, knowledge metrics and valuation, knowledge mapping and indexing, knowledge distribution and sharing, and knowledge storage [27]. KM programs can assist organizations to "know what they know and what they do not know". This is particularly related to the tacit knowledge that plays a vital role in the organization's survival and success in a highly competitive environment [12].

There are several variations of KM processes described in the literature (e.g., [28,29]). For instance, Lawson [30] proposed a KM process with six phases, basically involving the main stages described in other studies. The process begins with knowledge creation, where a standard for the type of knowledge is established. It also involves seeking knowledge and identifying its sources. Next, knowledge capture occurs where new knowledge is generated [30]. The knowledge captured undergoes filtration based on its usefulness, relevance and newness, evaluation, and structuring in the knowledge organization stage $[29,31,32]$. Then, knowledge storage takes place, where knowledge is preserved in databases and data warehouses that are accessible and secure [29,31]. The dissemination phase follows, where knowledge is passed on to employees across the organization [33]. Fugate et al. [29] argued that knowledge dissemination should be selective, where users receive knowledge relevant to their needs, and fast to maintain the integrity of the knowledge when it is used, before becoming outdated. Lastly, the knowledge utilization phase requires the use of knowledge to support the organization's objectives such as in decision-making [31-34].

The interdisciplinary fields of KM and SCM are growing areas of research [35]. Cantor et al. [36] showed the positive role of KM in supply chain risk mitigation. Diaz and Bailey [37] proposed the use of a defined KM framework for inventory control and identify and assess risks associated with this inventory and demand. Fugate et al. [33] identified the role of KM in creating competitive advantage on a global scale. Kogut and Zander [38] asserted that the growth of firm knowledge is a function of its knowledge stock as well as its continuous search for new knowledge elements and potential integration opportunities. Knowledge stock reflects the amount of knowledge elements that a firm has accumulated over time [38] and it is embedded in organizational routines, technologies, employees, and other types of resources [39,40]. Further, the existing type and level of knowledge stock in a firm influences its ability to absorb as well as generate new knowledge [41,42]. Hence, managing SCM knowledge has become an essential ingredient for superior supply chain performance [33]. Nonetheless, there remain areas that are understudied such as the impact of KM on firm performance in supplier-supplier relationship and factors that affect KM adoption, application, and storage in the supply network [33].

In their conceptual study, Ellram and Cooper [43] attested that looking at SCM as a philosophy provides an understanding of how SCM integration with other disciplines can contribute to 
competitive advantage. However, they briefly mentioned KM as a potentially beneficial candidate for cross-disciplinary integration with SCM, without providing details about the intricacies and promises of linking SCM with KM. In their systematic review of 176 articles published between 2001 and 2014 on the topic of KM in SCM, Bhosale and Kant [44] found that the vast majority of these articles were published after 2006. The relative newness of this link suggests that there are ample opportunities for research that integrates KM in SCM. Their study also found that the remarkable increase in attention to the importance of KM in SCM has focused on supply chain performance, relationships, and integration. On the KM side, the majority of such research has emphasized knowledge sharing and transfer.

More recently, the SCM literature has shown an increasing interest in knowledge and KM. Yang [45] provided empirical evidence for the impact of knowledge creation and distribution in the logistics function on firm performance. Knowledge sharing, among members of supply chain, has also been hailed as an important determinant of supply chain integration and performance. For instance, Bruque-Cámara et al. [46] found that when supply chain members manage trust and knowledge simultaneously, they become more fully committed to supply chain effectiveness through better delivery outcomes and greater flexibility. Nevertheless, internal integration through knowledge sharing has been recommended as a prerequisite to external integration [47]. This prerequisite has also been empirically supported in the study by Handfield et al. [48], wherein they showed that "increased levels of internal alignment facilitate the exchange and flow of knowledge between supply managers and supplier firms". Consequently, improving levels of knowledge would increase performance. The relationship between KM and supply chain performance has also been examined based on the SCOR model. For instance, Sangari et al. [31] employed structural equation modeling and a sample of 78 manufacturers to investigate the impact of KM processes on four of the five components of the SCOR model, as measures of supply chain performance.

\section{The K-SCM Knowledge Audit: A Methodology}

The knowledge audit methodology for KCRM is used as a template for the methodology for K-SCM, which will be discussed below. The concept of K-SCM knowledge audit lies at the nexus of the KM, auditing, and SCM literatures (Figure 1). The knowledge auditing process has been applied to knowledge-enabled CRM programs to identify and maximize the utilization of both existing and untapped customer knowledge resources [49] (also see Tiwana [50]; Tiwana [51], and Daghfous et al. [8]). It has also been used to better understand the processing and utilization of customer knowledge, to identify the gaps, barriers, and deficiencies of KCRM processes, and to achieve a better understanding of customer expectations [49]. The KSCM knowledge audit approach outlined in this paper provides a framework for ensuring that the various stages of the SCOR model are knowledge-enabled via a systematic approach to KM.

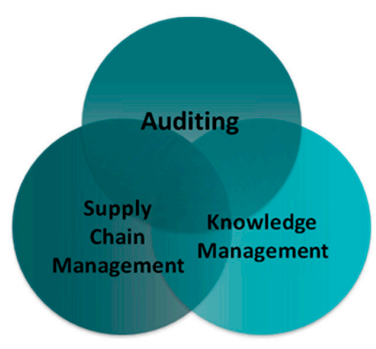

Figure 1. The realm of the K-SCM knowledge audit.

In this paper, we rely on the knowledge auditing approach proposed by Tiwana [50,51], which involves three major steps: (1) initiate the audit (i.e., define the goals, assemble the team, and identify constraints); (2) select reference measures and methods (i.e., determine the "ideal state", select the audit method, establish specific audit dimensions); and (3) perform the audit (i.e., ask the 
questions and document the knowledge assets into a knowledge inventory). The framework proposed in this paper focuses on the extent to which KM processes are explicitly put in place to facilitate K-SCM approaches, rather than on developing a content inventory of knowledge assets. Performing the audit involves asking targeted process-related questions and documenting the processes in place. Our proposed framework, however, includes a fourth, and final step in the knowledge audit, namely the use of the audit findings to generate ideas for using KM to improve K-SCM approaches.

\subsection{Step 1: Initiate the Audit}

The initiation phase of the knowledge audit involves defining the key goals to be achieved throughout the audit, assembling the team, and considering any existing constraint or limitation that may hamper the audit [50]. For the purposes of the proposed K-SCM knowledge audit, the goal is to identify how the organization integrates and applies principles of KM and SCM to deliver competitive advantage, and how, when, and to what extent supporting tools are used to facilitate K-SCM [51]. Given the cross-functional nature of SCM programs [52,53], audit teams should ideally include representatives from the sales, marketing, research and development ( $R$ and $D)$, and operations departments [54].

\subsection{Step 2: Select Reference Measures and Methods}

The second stage of the knowledge audit involves determining the 'ideal state', selecting the audit method, and establishing specific audit dimensions [50]. As the 'ideal state' is context specific, identifying performance metrics and benchmarks allows the organization to monitor progress toward achieving the highest levels of knowledge-enabled SCM. Knowledge audits can employ a range of methodologies, such as ethnographic studies, field observations, surveys, interview, and/or self-assessment check-lists [55]. Specific audit dimensions can vary considerably, depending on the frameworks and models adopted from the literature. For the purposes of the proposed K-SCM knowledge audit, audit dimensions should include both KM and SCM processes, as shown in Table 1.

In our integrated framework, a knowledge audit inspired by the K-CRM knowledge audit (see [2]) is developed and illustrated; and we called it the K-SCM knowledge audit. We integrate the four processes of KM discussed above (i.e., knowledge generation, codification, distribution, and utilization) with the five SCOR model components (i.e., plan, source, make, deliver, and return) (see Figure 2).

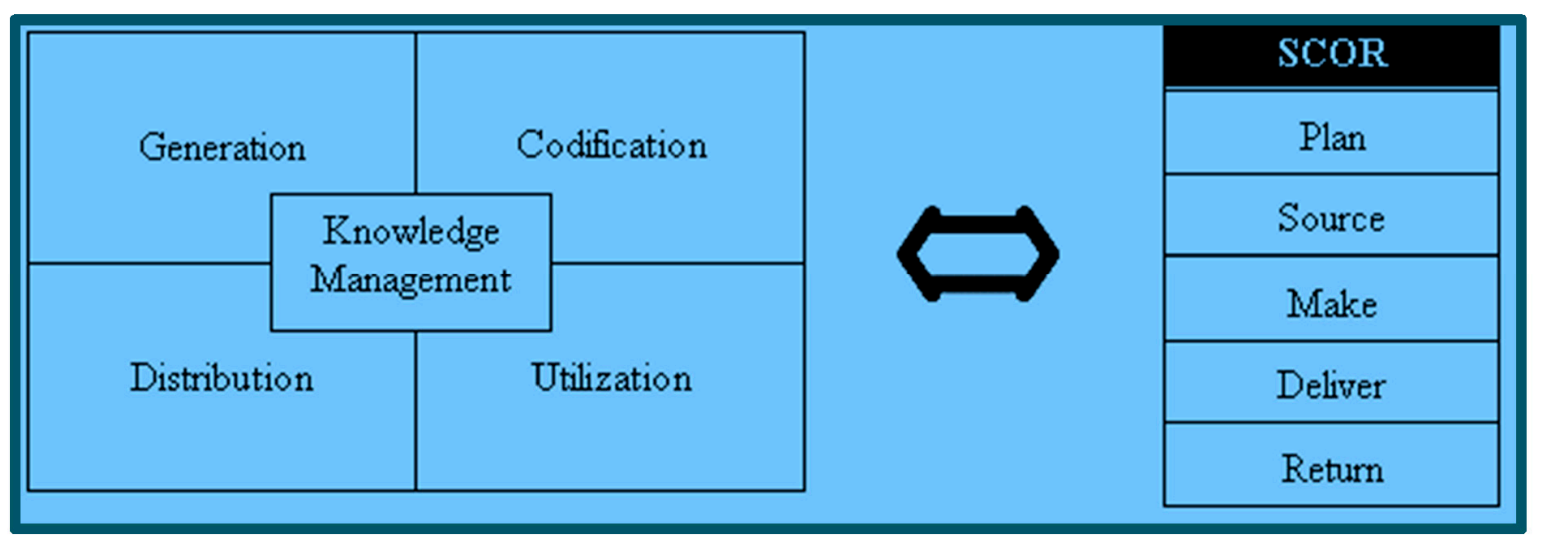

Figure 2. Integration of KM processes and SCM (SCOR model) components.

As a result of integrating KM processes with SCOR components, we developed a matrix (see Table 1). The proposed K-SCM knowledge audit covers every cell in this matrix by superposing $\mathrm{KM}$ processes with SCOR components. For example, cell " $3 b$ " relates to the process of knowledge codification as an enabler for the "Make" process in SCM. 
The four KM phases shown in each row include:

1. Knowledge generation: recognizing and creating new knowledge by monitoring the activities and behaviors of stakeholders.

2. Knowledge codification: converting knowledge into a documented form and storing it for future use. It facilitates the search and retrieval of relevant knowledge from the repositories. It also enables stakeholders to apply this knowledge in their decision-making.

3. Knowledge distribution: disseminating knowledge throughout the organization using "push" or "pull" technologies depending on the organization's culture and infrastructure. In the "pull" approach, users are expected to search for knowledge themselves either from existing knowledge repositories or organization memories. On the other hand, the "push" approach provides knowledge to users in terms of electronic newsletters, traditional class-room learning, or training [56].

4. Knowledge utilization: deploying knowledge and providing necessary feedback to stakeholders so that they are able to solve specific problems. The resulting cells shown in Table 1 provide specific areas of assessment during the K-SCM knowledge audit.

Table 1. Proposed framework for the K-SCM knowledge audit.

\begin{tabular}{lccccc}
\hline SCM Processes KM Activities & 1. Plan & 2. Source & 3. Make & 4. Deliver & 5. Return \\
\hline a. Generation & $1 \mathrm{a}$ & $2 \mathrm{a}$ & $3 \mathrm{a}$ & $4 \mathrm{a}$ & $5 \mathrm{a}$ \\
b. Codification & $1 \mathrm{~b}$ & $2 \mathrm{~b}$ & $3 \mathrm{~b}$ & $4 \mathrm{~b}$ & $5 \mathrm{~b}$ \\
c. Distribution & $1 \mathrm{c}$ & $2 \mathrm{c}$ & $3 \mathrm{c}$ & $4 \mathrm{c}$ & $5 \mathrm{c}$ \\
d. Utilization & $1 \mathrm{~d}$ & $2 \mathrm{~d}$ & $3 \mathrm{~d}$ & $4 \mathrm{~d}$ & $5 \mathrm{~d}$ \\
\hline
\end{tabular}

The audit questions relating to each of these sixteen cells were based on the studies by Liebowitz [57], Reinartz et al. [58], and Tiwana [59]. After reviewing the weaknesses and strengths of various questionnaires we developed a set of eighty questions. In order to determine the validity of the questions, we interviewed university professors and four practitioners who had been practicing $\mathrm{KM}$ and SCM for several years. Once these interviews were completed, we conducted a pre-test where students were asked individually to evaluate the questionnaire and comment on its clarity and understandability. Based on the feedback received, we clarified a few questions and removed six of the 80 questions, leaving us with 74 final questions.

\subsection{Step 3: Perform the Audit}

The third stage of the proposed K-SCM knowledge audit involves applying the specific audit questions and documenting the audit findings. We used a scoring mechanism for documenting the audit findings according to the extent to which tacit knowledge has been translated into explicit knowledge [59,60]. A rating from 0 to 8 was assigned by the auditor based on the answers related to a particular cell. Once a rating is assigned based on the answer to each question in each cell, an average score can be calculated for each cell and an average for each column can be calculated for further consideration. Subsequently, totals for each column and row were calculated to permit comparisons and analyses of low and high scoring SCM and KM activities. In this study, we are more interested in the SCM related activities. Therefore, we only calculate an average for each column. A low score relative to the scoring in other cells signals a need for K-SCM process improvement, potentially through better deployment of information systems. 


\subsection{Step 4: Develop a Plan for Process Improvement}

The results obtained from stage three can be used in stage four to identify knowledge gaps and process improvement opportunities within the organization's K-SCM program. The primary focus of this step consists of developing an improvement plan to create procedures that describe how the organization should operate. The next section of this paper provides a case study example to illustrate steps three and four of this approach to K-SCM knowledge auditing. In our integrated framework, a knowledge audit inspired by the K-CRM knowledge audit (see [2]) is developed and illustrated. We integrate the four processes of KM discussed above (i.e., knowledge generation, codification, distribution, and utilization) with the five SCOR model components (i.e., plan, source, make, deliver, and return) (see Figure 2).

\section{The K-SCM Knowledge Audit: An Illustrative Case}

Illustrative cases are primarily descriptive studies that typically utilize one or two instances of an event to show what a situation is like. Illustrative case studies mainly aim at making the unfamiliar familiar and give readers a common language about the topic in question. Case studies can also be illustrative in the sense of providing empirical exemplars of the embodiment of particular theories [61]. The company selected was a UAE-based manufacturing firm that offers advanced cable technology and related solutions. It had two factories in the UAE (Abu Dhabi and Dubai). The company, jointly owned by the governments of Dubai and Abu Dhabi (50\% each), had one of the most modern manufacturing units in the region, occupying an area of 590,000 square meters of land in Dubai and nearly 200,000 square meters in Abu Dhabi. It produced over 65,000 copper tons equivalent of low and medium voltage cables; and it was emerging as a leader and a prime choice for prestigious customers in the Middle East region.

\subsection{Data Collection and Analysis}

To collect the necessary data for this study, face-to-face interviews were conducted mainly with IT and SCM managers. Face-to-face interviews have an advantage over other methods such as emails in providing a high degree of interaction between the interviewer and the interviewees [62]. The data from each interview was either recorded on audio-tape or recorded on papers. All participants were knowledgeable about both their company's KM and SCM policies and practice. The interviews typically lasted between one and two hours, averaging ninety minutes. To ensure the objectivity of the data, anonymity of the interviewees and confidentiality of their responses are maintained. Other methods were used to collect the data include emails and telephone conversations.

The K-SCM knowledge audit followed the framework in Table 1. It is worth mentioning that a large portion of the questions were kept wide to give the interviewees great latitude in their answers. In addition, we encouraged the interviewees to focus on practical issues rather than on abstract concepts. By doing so, we could get the interviewees to take us through the actual process step-by-step, giving us a deeper understanding of the situation under study. In the familiarization stage, a full transcript of the data that was collected from the face-to-face interviews was compared with the interview notes and those collected from emails and telephone conversions. This enabled us to fully understand the data and fill any gaps in the transcripts. In the reflection stage, we summarized the data collected via face-to-face interviews for each interview. We, then, examined the overall results and made detailed notes representing interviewees' opinion. Then, we summarized the results into clusters. By doing so, we were able to compare our results with the theory and the results of prior research. The results and key findings are shown in Table 2. 
Table 2. The K-SCM knowledge audit results of CableCo.

\begin{tabular}{lcccccc}
\hline SCM Processes KM Activities & 1. Plan & 2. Source & 3. Make & 4. Deliver & 5. Return & Total \\
\hline a. Generation & $1 \mathrm{a}$ & $2 \mathrm{a}$ & $3 \mathrm{a}$ & $4 \mathrm{a}$ & $5 \mathrm{a}$ & 17 \\
b. Codification & $1 \mathrm{~b}$ & $2 \mathrm{~b}$ & $3 \mathrm{~b}$ & $4 \mathrm{~b}$ & $5 \mathrm{~b}$ & 23 \\
c. Distribution & $1 \mathrm{c}$ & $2 \mathrm{c}$ & $3 \mathrm{c}$ & $4 \mathrm{c}$ & $5 \mathrm{c}$ & 23 \\
d. Utilization & $1 \mathrm{~d}$ & $2 \mathrm{~d}$ & $3 \mathrm{~d}$ & $4 \mathrm{~d}$ & $5 \mathrm{~d}$ & 20 \\
Total & 21 & 15 & 16 & 23 & 8 & $83+83$ \\
\hline
\end{tabular}

\subsection{Illustrating the Proposed Framework in the Case Company (Performing the K-SCM Knowledge Audit)}

The K-SCM knowledge audit was conducted in the chosen company's SCM function as an illustration of the detailed application of the integrative framework developed above. The audit was conducted through interviews with the company's information and supply chain managers. The managers were asked several questions related to each cell in the matrix. After analyzing answers of the interview questions, we assigned the scores for each cell in the K-SCM knowledge audit based on the Bohn's scale of tacit/explicit knowledge (see Table 3).

Table 3. The Tacit/Explicit Knowledge Scale (adapted from Bohn [60] and Tiwana [50]).

\begin{tabular}{|c|c|}
\hline Stages of Knowledge & Description \\
\hline Stage 1: & $\begin{array}{l}\text { There is no knowledge available and no specific process for making a decision. } \\
\text { Instead, everything is done by trial and error. The company does not have a } \\
\text { process in place allowing it to distinguish positive vs. negative outcomes. }\end{array}$ \\
\hline Stage 2: & $\begin{array}{l}\text { Tacit knowledge is available and held by certain individuals. There is no process } \\
\text { in place to translate this tacit into explicit knowledge, and no systematic process } \\
\text { for making explicit knowledge available for decision-making. }\end{array}$ \\
\hline Stage 3: & $\begin{array}{l}\text { Tacit knowledge is made available in the form of heuristics (i.e., rules of thumb) } \\
\text { that usually work well to enable decision-making. }\end{array}$ \\
\hline Stage 4: & $\begin{array}{l}\text { Some tacit knowledge is codified, but there is no evidence that this codified } \\
\text { (i.e., explicit) knowledge is systematically used within the company. }\end{array}$ \\
\hline Stage 5: & $\begin{array}{l}\text { There is evidence of a process for making explicit knowledge available. However, } \\
\text { in order to use this knowledge optimally for decision-making, employees require } \\
\text { access to tacit knowledge held by certain people within the company. There is no } \\
\text { evidence that this access is systematic or stable. }\end{array}$ \\
\hline Stage 6: & $\begin{array}{l}\text { Explicit knowledge is available to enable decision-making under typical } \\
\text { circumstances. However, in special circumstances, input may be required from } \\
\text { the tacit knowledge held by certain individuals within the company. There is } \\
\text { some evidence of a systematic process for accessing this tacit knowledge when } \\
\text { needed. Explicit knowledge is revalidated every time it is used. }\end{array}$ \\
\hline Stage 7: & $\begin{array}{l}\text { Scientific models of the processes exist, and irrelevant practices are regularly } \\
\text { recognized and eliminated. Tacit knowledge is used at a minimum level. } \\
\text { Explicit knowledge is revalidated every time it is used. Explicit knowledge can be } \\
\text { used to simulate conditions and conduct what-if analyses, and these analyses } \\
\text { enable the company to modify behaviour accordingly. Knowledge sharing is } \\
\text { supported by the company's culture, and any harm caused by the loss of an } \\
\text { employee is minimized due to strong processes of knowledge codification. }\end{array}$ \\
\hline Stage 8: & $\begin{array}{l}\text { Complete explicit knowledge is available for decision-making. There is a } \\
\text { systematic process for regularly codifying tacit knowledge. This is an ideal state, } \\
\text { very rarely achieved. }\end{array}$ \\
\hline
\end{tabular}


The K-SCM knowledge audit was conducted at CableCo's SCM as an illustration of the detailed application of the integrative framework developed previously. The managers were asked questions about each cell in the matrix, which means about each KM and SCM area. The following are examples of the interview questions and a summary of the findings:

1.a How does the company learn about processes, techniques, methods, and IT solutions in SCM strategy planning, measuring performance, and development of SCM?

The company has an academy to develop, research, and trains our employees about the new trends in the SCM strategy and planning, but only experienced people can do that.

1.b How does the company document knowledge used or acquired in SCM strategy planning, measuring performance, and development of SCM?

The company has a content management system that enables documentation with multimedia capabilities, but very few employees know how to use it.

1.c How does the company internally distribute and share knowledge used or acquired in SCM strategy planning, measuring performance, quality, and development of SCM? (Share internally within the SCM or across departments)

Every month top supply chain managers, middle managers, and operation managers meet and discuss both formally and informally issues about supply chain strategy, performance, quality, and how to improve them.

1.d How does the company utilize acquired or documented knowledge in SCM strategy planning, measuring performance, quality, and development of SCM?

Usually when they decide to engage in a new SCM initiative or development plans, there are controls to measure to what extent employees are performing them right. Therefore, after training or learning employees make sure to follow the new controls and process and utilize the new knowledge.

2.a How does the company learn about processes, techniques, methods, technologies, and IT solutions in managing supplier relationship, purchasing, and receiving processes, and inventory management?

There is no a specific procedure for that. However, there are some employees that are responsible and have the expertise to research and learn about inventory and supplier relationships.

2.b How does the company document knowledge used or acquired in managing supplier relationship, purchasing and receiving processes, and inventory management?

There are very useful manuals and documentation in purchasing, receiving, inventory, and supplier relationship that are updated regularly. However, there are certain employees that are responsible to do that; not everyone can.

2.c How does the company internally distribute and share knowledge used or acquired in managing supplier relationships, purchasing and receiving processes, and inventory management? (Share internally within the SCM or across departments)

There is no special procedure for knowledge sharing in supply chain sourcing. However, we usually do that in meetings and informally. We rely on rules of thumb.

2.d How does the company utilize acquired or documented knowledge about the supplier relationship, purchasing and receiving processes, and inventory management?

Just like in planning, there are always new controls to measure the utilization of new knowledge and initiatives but if these controls are not set by certain supply chain manager, no one can utilize the new knowledge.

3.a How does the company learn about processes, techniques, methods, technologies and IT solutions in manufacturing, testing, and packaging?

CableCo depends on some very specific senior engineers and consultants about the manufacturing methods and quality testing techniques. 
3.b How does the company document knowledge used or acquired in manufacturing, testing, and packaging?

There are large manuals that are updated regularly about all the manufacturing methods and technologies, and the documentation of any new process is well-structured.

3.c How does the company internally distribute and share knowledge used or acquired in manufacturing, testing, and packaging? (Share internally within the SCM or across departments)

There are many publications and brochures that are distributed to all departments to provide the methods and technologies used in manufacturing, packaging and testing. The knowledge in this area is very important and everyone in the company must know about it.

3.d How does the company utilize acquired or documented knowledge about the manufacturing, testing, and packaging?

The utilization in manufacturing relies on the controls and supervision of the senior engineers in the factories. There are no structured methods. CableCo depends on the tacit expertise of the senior engineers that chose to use new knowledge.

4.a How does the company learn about processes, techniques, methods, technologies and IT solutions in managing customer orders, logistics, and invoicing?

CableCo is partnering with an external business solutions provider to help them stay updated with the latest trends in logistics and ordering. The job of this external agency is to provide CableCo with structured and new knowledge in SCM delivery.

4.b How does the company document knowledge used or acquired in managing customer orders, logistics, and invoicing?

The external agency is also providing all the documentation to help CableCo's employee with all the resources they need in delivering their products.

4.c How does the company internally distribute and share knowledge used or acquired in managing customer orders, logistics, and invoicing? (Share internally within the SCM or across departments)

Usually, senior supply chain managers learn about all the new knowledge provided by the external agency and give training sessions, presentations, and documents to share and distribute the knowledge with SCM middle managers and operation managers.

4.d How does the company utilize acquired or documented knowledge about managing customer orders, logistics, and invoicing?

Senior supply chain managers set controls in training and presentations and carefully supervise the performance of the employees to encourage the utilization.

5.a How does the company learn about processes, techniques, methods, technologies, and IT solutions in managing the return of defective or excess products, and customer support?

CableCo does not have a lot in reverse logistics; therefore, there are structured method for learning about reverse logistics in the academy. The company relies on the knowledge and decisions of senior supply chain managers to do reverse logistics tasks.

5.b How does the company document knowledge used or acquired in managing the return of defective or excess products, and customer support?

The company relies on the decisions of senior SCM and does not have a structured method for documenting knowledge in this area.

5.c How does the company internally distribute and share knowledge used or acquired in managing the return of defective or excess products, and customer support? (Share internally within the SCM or across departments)

Since it is unusual to have reverse logistics, the company relies on the expertise of the senior supply chain managers to share knowledge with other employees. 
5.d How does the company utilize acquired or documented knowledge about managing the return of defective or excess products, and customer support?

Since it is unusual to have reverse logistics, the company relies on the expertise of the senior supply chain managers to set controls to measure the utilization of knowledge in this area.

\subsection{Analysis and Evaluation}

After analyzing answers of the interview questions, we assigned the scores for each cell in the K-SCM knowledge audit based on the Bohn's scale of tacit/explicit knowledge (see Table 3). Upon assigning scores and calculating totals in the framework of K-SCM knowledge audit, we analyzed the results and identified possible weaknesses, strengths, and gaps. This would help the firm understand where its SCM function (processes, activities, systems, and initiatives) stand in terms of knowledge and KM. It would also help determine how ready the firm is to engage in K-SCM, as well as identify opportunities for improvements. The results shown in Table 4 indicate that the "planning" component of the SCOR framework had good scores since the firm had structured methods for all the four KM activities. However, for the "source" component, the tacit nature of knowledge was quite high. In the "make" component, the firm also relied on some tacit knowledge of its senior factory engineers who controlled the processes of knowledge generation and utilization. Meanwhile, the "delivery" component was the best structured and the least tacit in the firm's SCM function. There were structured methods for every KM process. The apparent reason behind this was that the firm was outsourcing the logistics component to an external agency, which seemed to have good KM. Finally, it appeared that the main knowledge weakness of the firm in this case study was the reverse logistics component of the SCM process. The company relied completely on the tacit knowledge of its senior supply chain managers with regard to return SCM.

Table 4. K-SCM knowledge audit results of CableCo.

\begin{tabular}{lcccccc}
\hline SCM Processes KM Activities & 1. Plan & 2. Source & 3. Make & 4. Deliver & 5. Return & Total \\
\hline a. Generation & 5 & 2 & 2 & 6 & 2 & 17 \\
b. Codification & 4 & 5 & 6 & 6 & 2 & 23 \\
c. Distribution & 7 & 3 & 6 & 5 & 2 & 23 \\
d. Utilization & 5 & 5 & 2 & 6 & 2 & 20 \\
Total & 21 & 15 & 16 & 23 & 8 & $83+83$ \\
\hline
\end{tabular}

\subsection{Managerial Implications}

The firm's SCM components exhibited good knowledge sharing and documenting methods. However, this firm should consider better deployment of specific enabling tools that help facilitate knowledge generation and utilization. Moreover, reverse logistics was a major issue and the company should learn more about the application of SCM returns and decrease its reliance on the tacit knowledge of specific senior supply chain managers. Indeed losing these key people (i.e., sole knowledge owners) could cause major problems. The company should also build reverse logistics scenarios and engage middle and operation managers in decision-making more often to make this process more structured/explicit and less tacit. Thereafter, it should document the related steps and processes.

\section{Summary, Limitations, and Implications for Sustainable SCM}

\subsection{Summary and Limitations}

This paper developed and introduced a methodology for the K-SCM knowledge audit, which combines KM processes with SCM's SCOR model components. This new concept would enable companies to improve their expertise and leverage their knowledge in the SCM function. It also fosters knowledge generation, codification, distribution, and utilization in the supply chain. 
Further, we urge firms to resort to our auditing methodology to determine where to start and where the company stands, in terms of augmenting SCM with knowledge and KM systems and processes. The knowledge audit for K-SCM assesses the current level of KM in the SCM function and identifies the opportunities for improvements. After developing and proposing a framework that uses dimensions of KM and SCOR model components, we performed the audit in a UAE-based company by focusing on its supply chain operations.

The results of the interviews determined the scores mapped to each cell in the matrix of the framework and allowed us to analyze and assess the company's level of K-SCM. Future research should undertake more field studies as well as survey methodologies to confirm, identify and explore the linkages between K-SCM knowledge audit scores and various measures of SCM performance. In addition, future research should investigate how knowledge auditing approaches could be applied to other operations and general management processes, such as process redesign, continuous improvement, new product development, and SSCM.

\subsection{Implications for Sustainable SCM (SSCM)}

In this subsection, we focus on sustainability in the SCM function and link it to the K-SCM knowledge audit proposed above. Sarkis et al. [63] relied on various organizational theories to investigate the adoption, diffusion and outcomes of green SCM practices [63]. Such literature reviews outlined numerous opportunities for further advancing theory, methodology, and the managerial relevance of future inquiries. More relevant to our study is Sarkis et al.'s [63] assertion that there is a dearth of research on the value and contribution of knowledge sharing, capabilities development, and learning in the adoption and successful implementation of SSCM practices [64].

In practice, there are several ways in which firms could implement sustainability to reduce waste and decrease the impact of supply chain activities on the environment. For instance, they could embark on decreasing packaging, producing recyclable goods, buying locally in order to decrease fuel costs, following an efficient distribution process, and working with suppliers to further reduce their negative environmental impact. Therefore, firms can incorporate sustainability initiatives at every stage of the SCOR model. In addition to the increasingly common practices of sustainability auditing, focal firms could map SSCM initiatives onto the K-SCM knowledge audit framework proposed in this paper, thereby enhancing the success of their various SSCM initiatives.

For instance, firms could generate new SSCM knowledge by investing in exploratory experiments and learning programs related to new techniques, ideas, trends, and best practices that can be used to launch new SSCM initiatives or improve existing ones. Tacit knowledge related to SSCM should be codified and disseminated throghout the organization to maximize its value and its impact on customer satisfaction, supply chain performance, and achieve other sustainability objectives, such as waste reduction, social responsibility, and environmental protection. As mentioned above, these knowledge-enabled and even knowledge-enhanced SSCM initiatives should be proactively initiated at each stage of the SCOR model. For instance, a knowledge repository could greatly enhance the focal firm's ability to select the most sustainable suppliers. Knowlede transfer to key suppliers could also be planned to develop key suppliers' capabilities with respect to SSCM, several tiers upstream.

Author Contributions: Abdelkader Daghfous conceived and designed the framework, conducted the case study, and analyzed the results. Taisier Zoubi reviewed the related literature and extensively revised and edited the whole manuscript. Both authors conducted the revisions and approved the publication.

Conflicts of Interest: The authors declare no conflict of interest. 


\section{References}

1. Gorla, N.; Chinta, R.; Chu, T.W. An enhanced business process re-engineering model for supply chain management and a case study. J. Inform. Technol. Case Appl. Res. 2007, 9, 5-27. [CrossRef]

2. Gebert, H.; Geib, M.; Kolbe, L.; Brenner, W. Knowledge-enabled customer relationship management: Integrating customer relationship management and knowledge management concepts[1]. J. Knowl. Manag. 2003, 7, 107-123. [CrossRef]

3. Dries, L.; Gorton, M.; Urutyan, V.; White, J. Supply chain relationships, supplier support programmes and stimulating investment: Evidence from the armenian dairy sector. Supply Chain Manag. 2014, 19, 98-107. [CrossRef]

4. Lang, J.C. Managing in knowledge-based competition. J. Organ. Chang. Manag. 2001, 14, 539-553. [CrossRef]

5. Wagner, S.M.; Krause, D.R. Supplier development: Communication approaches, activities and goals. Int. J. Prod. Res. 2009, 47, 3161-3177. [CrossRef]

6. Ozkul, A.; Barut, M. Measuring supply chain relationships: A social network approach. Int. J. Integr. Supply Manag. 2009, 5, 38-61. [CrossRef]

7. Pearson, J.N.; Gritzmacher, K.J. Integrating purchasing into strategic management. Long Range Plan. 1990, 23, 91-99. [CrossRef]

8. Daghfous, A.; Ahmad, N.; Angell, L.C. The kcrm knowledge audit: Model and case illustration. Vine 2013, 43, 185-209. [CrossRef]

9. Daghfous, A.; Khawaja, A. Knowledge-enabled scm auditing (k-scm): A methodology and a case illustration. In Proceedings of the 2010 IEEE International Conference on Management of Innovation and Technology (ICMIT), Singapore, 2-5 June 2010; pp. 964-969.

10. Yekta, R.R. Investigating the dimensionality of an admission specific purpose language test. World Appl. Sci. J. 2013, 4, 498-519.

11. Choy, S.-Y.; Lee, W.; Cheung, C.F. A systematic approach for knowledge audit analysis: Integration of knowledge inventory, mapping and knowledge flow analysis. J. Univ. Comput. Sci. 2004, 10, 674-682.

12. Cheung, C.F.; Li, M.L.; Shek, W.Y.; Lee, W.B.; Tsang, T.S. A systematic approach for knowledge auditing: A case study in transportation sector. J. Knowl. Manag. 2007, 11, 140-158. [CrossRef]

13. Wang, J.; Xiao, J. Knowledge management audit framework and methodology based on processes. J. Technol. Manag. China 2009, 4, 239-249. [CrossRef]

14. Yip, J.S.; Lee, R.W.; Tsui, E. Examining knowledge audit for structured and unstructured business processes: A comparative study in two Hong Kong companies. J. Knowl. Manag. 2015, 19, 514-529. [CrossRef]

15. Kane, G.C. The evolutionary implications of social media for organizational knowledge management. Inform. Organ. 2017, 27, 37-46. [CrossRef]

16. Srivastava, S.K. Green supply-chain management: A state-of-the-art literature review. Int. J. Manag. Rev. 2007, 9, 53-80. [CrossRef]

17. Carter, C.R.; Liane Easton, P. Sustainable supply chain management: Evolution and future directions. Int. J. Phys. Distrib. Logist. Manag. 2011, 41, 46-62. [CrossRef]

18. Carter, C.R.; Jennings, M.M. Logistics social responsibility: An integrative framework. J. Bus. Logist. 2002, 23, 145-180. [CrossRef]

19. Theeranuphattana, A.; Tang, J.C. A conceptual model of performance measurement for supply chains: Alternative considerations. J. Manuf. Technol. Manag. 2007, 19, 125-148. [CrossRef]

20. Ntabe, E.N.; LeBel, L.; Munson, A.D.; Santa-Eulalia, L.-A. A systematic literature review of the supply chain operations reference (scor) model application with special attention to environmental issues. Int. J. Product. Econ. 2015, 169, 310-332. [CrossRef]

21. Craighead, C.W.; Hult, G.T.M.; Ketchen, D.J. The effects of innovation-cost strategy, knowledge, and action in the supply chain on firm performance. J. Oper. Manag. 2009, 27, 405-421. [CrossRef]

22. Omotayo, F.O. Knowledge Management as an Important Tool in Organisational Management: A Review of Literature. Librar. Philosoph. Pract. 2015. Available online: http://digitalcommons.unl.edu/cgi/viewcontent. cgi?article $=3330$ \&context=libphilprac (accessed on 10 February 2017).

23. Davenport, T.H.; Prusak, L. Working Knowledge: How Organizations Manage What They Know; Harvard Business Press: Boston, MA, USA, 1998. 
24. Hylton, A. The Role of Knowledge Audit in Corporate Intranet Design. 2002. Available online: http:/ /www.providersedge.com/docs/km_articles/Role_of_K_Audit_in\%20Corp_Intranet_Design.pdf (accessed on 10 February 2017).

25. Polanyi, M. The Tacit Dimension; Anchor Books: Garden City, NY, USA, 1967.

26. Bose, R.; Sugumaran, V. Application of knowledge management technology in customer relationship management. Knowl. Process. Manag. 2003, 10, 3-17. [CrossRef]

27. Gloet, M. Knowledge management audit: The role of managers in articulating and integrating quality practices. Manag. Audit. J. 2002, 17, 310-316. [CrossRef]

28. Soliman, K.S.; Janz, B.D.; Raisinghani, M.S.; Meade, L.L. Strategic decisions in supply-chain intelligence using knowledge management: An analytic-network-process framework. Supply Chain. Manag. 2005, 10, 114-121.

29. Fugate, B.S.; Autry, C.W.; Davis-Sramek, B.; Germain, R.N. Does knowledge management facilitate logistics-based differentiation? The effect of global manufacturing reach. Int. J. Prod. Econ. 2012, 139, 496-509. [CrossRef]

30. Lawson, S. Examining the Relationship between Organizational Culture and Knowledge Management. Ph.D. Thesis, International Business Administration, Nova Southeastern University, Fort Lauderdale, FL, USA, 2003.

31. Sangari, M.S.; Hosnavi, R.; Zahedi, M.R. The impact of knowledge management processes on supply chain performance: An empirical study. Int. J. Logist. Manag. 2015, 26, 603-626. [CrossRef]

32. Allameh, S.M.; Zare, S.M. Examining the impact of km enablers on knowledge management processes. Procedia Comput. Sci. 2011, 3, 1211-1223. [CrossRef]

33. Fugate, B.S.; Stank, T.P.; Mentzer, J.T. Linking improved knowledge management to operational and organizational performance. J. Oper. Manag. 2009, 27, 247-264. [CrossRef]

34. Alavi, M.; Leidner, D.E. Review: Knowledge management and knowledge management systems: Conceptual foundations and research issues. MIS Q. 2001, 25, 107-136. [CrossRef]

35. Cerchione, R.; Esposito, E.; Spadaro, M.R. A literature review on knowledge management in smes. Knowl. Manag. Res. Pract. 2016, 14, 169-177. [CrossRef]

36. Cantor, D.; Blackhurst, J.; Pan, M.; Crum, M. Examining the role of stakeholder pressure and knowledge management on supply chain risk and demand responsiveness. Int. J. Logist. Manag. 2014, 25, $202-223$. [CrossRef]

37. Diaz, R.; Bailey, M. Building knowledge to improve enterprise performance from inventory simulation models. Int. J. Prod. Econ. 2011, 134, 108-113. [CrossRef]

38. Kogut, B.; Zander, U. Knowledge of the firm, combinative capabilities, and the replication of technology. Organ. Sci. 1992, 3, 383-397. [CrossRef]

39. Dierickx, I.; Cool, K. Asset stock accumulation and sustainability of competitive advantage. Manag. Sci. 1989, 35, 1504-1511. [CrossRef]

40. Grant, R.M. Toward a knowledge-based theory of the firm. Strateg. Manag. J. 1996, 17, 109-122. [CrossRef]

41. Cohen, W.M.; Levinthal, D.A. Absorptive capacity: A new perspective on learning and innovation. Adm. Sci. Q. 1990, 35, 128-152. [CrossRef]

42. Smith, K.G.; Collins, C.J.; Clark, K.D. Existing knowledge, knowledge creation capability, and the rate of new product introduction in high-technology firms. Acad. Manag. J. 2005, 48, 346-357. [CrossRef]

43. Ellram, L.M.; Cooper, M.C. Supply chain management: It's all about the journey, not the destination. J. Supply Chain Manag. 2014, 50, 8-20. [CrossRef]

44. Bhosale, V.A.; Kant, R. Metadata analysis of knowledge management in supply chain: Investigating the past and predicting the future. Bus. Process. Manag. J. 2016, 22, 140-172. [CrossRef]

45. Yang, C.-C. Leveraging logistics learning capability to enable logistics service capabilities and performance for international distribution center operators in taiwan. Int. J. Logist. Manag. 2016, 27, 284-308. [CrossRef]

46. Bruque-Cámara, S.; Moyano-Fuentes, J.; Maqueira-Marín, J.M. Supply chain integration through community cloud: Effects on operational performance. J. Purch. Supply Manag. 2016, 22, 141-153. [CrossRef]

47. Wisner, J.D.; Tan, K.-C.; Leong, G.K. Principles of Supply Chain Management: A Balanced Approach; Cengage Learning: Boston, MA, USA, 2014. 
48. Handfield, R.B.; Cousins, P.D.; Lawson, B.; Petersen, K.J. How can supply management really improve performance? A knowledge-based model of alignment capabilities. J. Supply Chain Manag. 2015, 51, 3-17. [CrossRef]

49. Zhu, Z. Knowledge of the natural and the social: How are they different and what do they have in common? Knowl. Manag. Res. Pract. 2010, 8, 173-188. [CrossRef]

50. Tiwana, A.; Williams, M. The Essential Guide to Knowledge Management: E-business and Crm Applications; Prentice Hall PTR: Saddle City, NJ, USA, 2000.

51. Tiwana, A. The Knowledge Management Toolkit: Orchestrating It, Strategy, and Knowledge Platforms; Pearson Education India: Noida, India, 2002.

52. Corso, M.; Dogan, S.F.; Mogre, R.; Perego, A. The role of knowledge management in supply chains: Evidence from the italian food industry. Int. J. Netw. Virtual Organ. 2010, 7, 163-183. [CrossRef]

53. Hanvanich, S.; Dröge, C.; Calantone, R. Reconceptualizing the meaning and domain of marketing knowledge. J. Knowl. Manag. 2003, 7, 124-135. [CrossRef]

54. Srivastava, R.K.; Shervani, T.A.; Fahey, L. Marketing, business processes, and shareholder value: An organizationally embedded view of marketing activities and the discipline of marketing. J. Market. 1999, 168-179. [CrossRef]

55. Forkmann, S.; Henneberg, S.C.; Naudé, P.; Mitrega, M. Supplier relationship management capability: A qualification and extension. Ind. Market. Manag. 2016, 57, 185-200. [CrossRef]

56. Mahé, S.; Rieu, C. A pull approach to knowledge management. In Proceedings of the Practical Aspects of Knowledge Management PAKM98, Basel, Switzerland, 29-30 Octorber 1998; pp. 11-19.

57. Liebowitz, J. Building Organizational Intelligence: A Knowledge Management Primer; CRC Press: Boca Raton, FL, USA, 1999; Volume 1.

58. Reinartz, W.; Krafft, M.; Hoyer, W.D. The customer relationship management process: Its measurement and impact on performance. J. Mark. Res. 2004, 41, 293-305. [CrossRef]

59. Tiwana, A. An empirical study of the effect of knowledge integration on software development performance. Inform. Softw. Technol. 2004, 46, 899-906. [CrossRef]

60. Bohn, R.E. Measuring and managing technological knowledge. Sloan Manag. Rev. 1994, 36, 61-73.

61. Burnett, S.; Illingworth, L.; Webster, L. Knowledge auditing and mapping: A pragmatic approach. Knowl. Process. Manag. 2004, 11, 25-37. [CrossRef]

62. Scapens, R.W. Doing case study research. In The Real Life Guide to Accounting Research; Elsevier: Amsterdam, The Netherlands, 2004; pp. 257-279.

63. Sarkis, J.; Zhu, Q.; Lai, K.-H. An organizational theoretic review of green supply chain management literature. Int. J. Prod. Econ. 2011, 130, 1-15. [CrossRef]

64. Easterby-Smith, M.; Thorpe, R.; Lowe, A. Management Research: [An Introduction], 2nd ed.; SAGE: London, UK, 2002; p. 194.

(C) 2017 by the authors. Licensee MDPI, Basel, Switzerland. This article is an open access article distributed under the terms and conditions of the Creative Commons Attribution (CC BY) license (http:/ / creativecommons.org/licenses/by/4.0/). 